\title{
The Impact of Brand Equity Drivers on Consumer-based Brand Equity in the Sport Service Setting
}

\author{
Brian S. Gordon ${ }^{1} \&$ Jeffrey D. James ${ }^{2}$ \\ ${ }^{1}$ Department of Health, Sport, \& Exercise Science, University of Kansas, Lawrence, USA \\ ${ }^{2}$ Department of Sport Management, Florida State University, Tallahassee, USA \\ Correspondence: Brian S. Gordon, Department of Health, Sport, \& Exercise Science, University of Kansas, \\ Room146C-1 Robinson Center, Lawrence, KS 66045-7567, USA. Tel: 785-864-4451.
}

Received: April 25, 2017

Accepted: May 15, 2017

Online Published: May 23, 2017

doi:10.5430/ijba.v8n3p55

URL: https://doi.org/10.5430/ijba.v8n3p55

\begin{abstract}
The importance of brand equity to a firm has been well documented by previous literature. Brands with high equity allow a firm to charge a premium price as well as garner a larger market share in relation to competitors (Simon \& Sullivan, 1993). From the consumer's perspective, previous research has failed to explain precisely how consumers perceive and become loyal to specific brands. Therefore, this study constructed and tested a consumer-based brand equity model based on Keller's (2003a) brand equity pyramid that explains how consumer perceptions influence brand resonance. Data were collected from a general consumer sample $(n=787)$ in a mid-sized southeastern community in order to validate the consumer-based brand equity model. The results from an examination of the structural model confirmed a significant relationship between brand awareness and brand associations as posited by previous research. Brand associations were found to have a significant impact on a consumer's cognitive evaluation (brand superiority) and affective response (brand affect) to a focal brand in the service realm. Further, this study highlighted the important role that emotions play in the process of building strong brand equity. Cumulatively, these findings revealed that two attitudinal constructs (brand superiority and brand affect) played a differential role in the brand association-brand resonance relationship in the services context.
\end{abstract}

Keywords: brand associations, brand equity, brand affect, brand resonance, service brand

\section{Introduction}

Firms are continually interested in building strong brands with positive equity. The strength of a brand lies in the mind of the consumer yet it is still unclear exactly how brand equity is fostered, managed, and maintained (Keller, 2003b). Although the lion's share of research on brand equity has been conducted in the context of traditional goods, the importance of brand equity is being realized with other products such as in the realm of service brands.

Although an emphasis on brand management strategies is a relatively new phenomenon in the sport industry, the importance of branding has been evident for traditional goods and service firms since the late 1980's (Srinivasan, Park, \& Chang, 2005). Research has consistently shown that there are numerous benefits of strong brands for both consumers and firms alike. For consumers, strong brands reduce the perceived risk and search costs, enhance the likelihood of future consumption, act as a signal of differentiation, and can strengthen social identity (Cobb-Walgren, Ruble, \& Donthu, 1995; Davcik and Sharma, 2015; Kayaman \& Arasli, 2007; Watkins, 2014). Due to the strength of a brand, organizations can charge a premium price for their products, have the ability to gain market share, can maintain customer loyalty, offer success brand extension opportunities and can influence their consumers to spread positive word of mouth (Brady, Cronin, Fox, \& Roehm, 2008; Cobb-Walgren et al., 1995; Sangster, Wolton, \& McKenney, 2001).

Although the importance of brand equity has been posited, the manner by which the hypothesized drivers of brand equity impact consumers' behavioral intentions has rarely been the focus of empirical investigations (see Bauer, Sauer, \& Schmitt, 2005; Park, MacInnis, Priester, Eisingerich, \& Iacobucci, 2010; Taylor, Celuch, \& Goodwin, 2004 for exceptions). It is important to empirically assess how drivers of brand equity such as brand awareness and brand associations impact consumers' behavioral intentions for numerous reasons. First, firms spend millions each year on 
activities to enhance their brand. Advancing our understanding of how to build brand equity can help organizations become more efficient in their brand management strategies.

Additionally, there has been a tenuous link established between consumers' behavioral intentions and a firm's increased financial performance. Numerous authors have suggested that consumer perceptions of a brand will have an impact on financial outcomes such as relative price and market share for a firm's offerings (Aaker, 1996; Baldinger \& Robinson, 1996; Bello \& Holbrook, 1995; Keller, 1993). More specifically, sport brands with high equity have been found to sell more brand-laden merchandise as well as have consumers that are willing to pay a higher price for tickets to the sporting events (Boone, Kochunny, \& Wilkins, 1995; Gladden \& Milne, 1999). Such findings illustrate the importance of understanding how organizations can influence consumers' behavioral intentions through the strategic implementation of brand management activities. The reasons cited above provide a good case as to the importance of investigating the relationship between the drivers of brand equity and behavioral intentions.

Besides the importance of determining the relationship between the drivers of brand equity and consumers' behavioral intentions, this study attempted to address weaknesses of prior conceptualizations. Previous studies of consumer-based brand equity (Akin, 2016; Gladden \& Funk, 2002; Ross, James, \& Vargas, 2006; Su \& Tong, 2015) have examined specific drivers of brand equity such as brand awareness and brand associations yet these studies have not accounted for other constructs that play a vital role in influencing a consumer's behavioral intentions. Specifically, the Marketing Science Institute (2008) has identified the consumer's emotional response to a brand as an important area of future inquiry. This area may take on greater importance in the realm of sport services due to the great affective impact the spectator sport product has on its consumers (Mullin, Hardy, \& Sutton, 2007). Therefore, the purpose of this study involved two facets. First, a theoretical model of consumer-based brand equity was established that related various aspects of brand equity to consumer behavioral intentions. Second, the constructs were operationalized and the relationships among the dimensions of brand equity were empirically examined.

\section{Literature Review}

\subsection{Keller's (2003a) Consumer-based Brand Equity Pyramid}

The foundation for the conceptual model in this study is illustrated in Figure 1. The model is divided into six distinct drivers: brand salience, brand performance, brand imagery, consumer judgments, consumer feelings, and consumer-brand resonance. The conceptualization of the six drivers was based upon Keller's (2003a) consumer-based brand equity pyramid, which posits that brand equity is built sequentially through the six drivers. A particular feature of Keller's pyramid is that one level must be achieved before a consumer could experience or engage in the next. However, there are some fundamental differences in the conceptualization of this study and the original consumer-based brand equity pyramid that was posited by Keller.

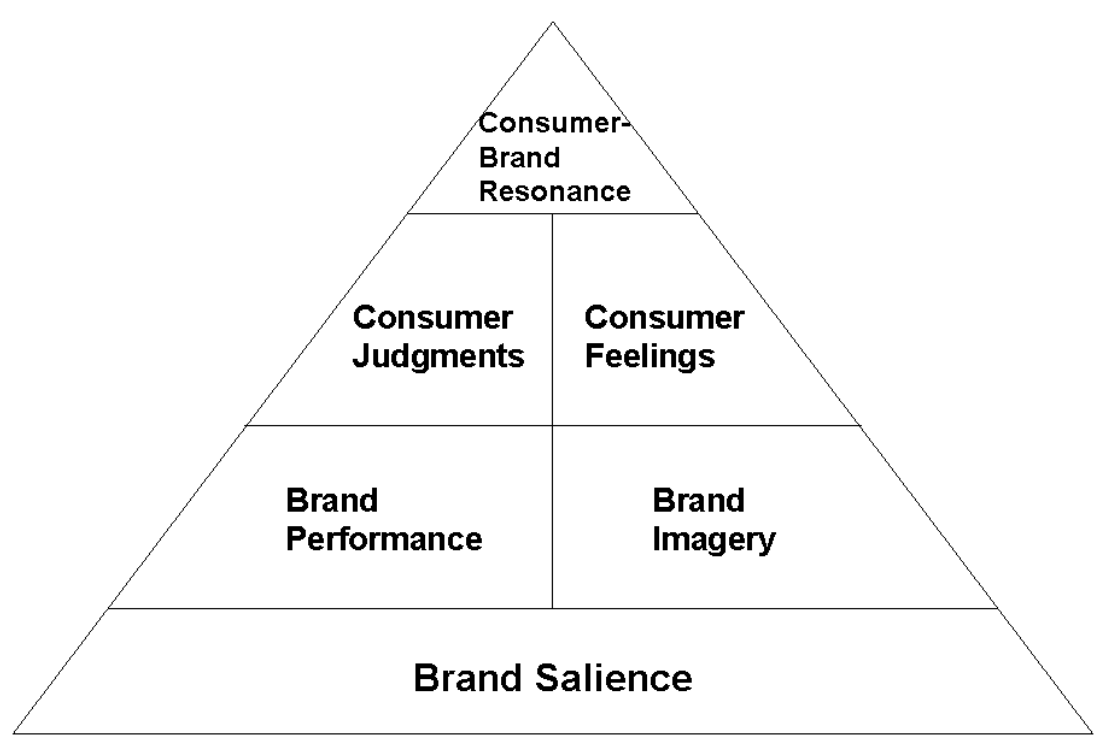

Figure 1. Consumer-based brand equity pyramid (Keller, 2003a) 
The consumer-based brand equity pyramid is a sequential framework for how organizations can build a strong brand and includes four steps, each of which needs to be successfully accomplished to reach the next.

Keller (2003a) contends the first step in building a strong brand is creating brand saliency in the mind of the consumer. Brand salience refers to aspects of the awareness of a brand such as the top-of-mind awareness of the brand, retreivability of the brand, and the overall strength of awareness. The second step in building a strong brand is the creation of a product that meets or exceeds the functional and psychological or social needs of the consumer. Brand performance and brand imagery are key aspects of achieving this step in building a strong brand. The key aspect of achieving this goal is to build strong, favorable, and unique brand associations related to the functional and experiential aspects of the brand.

Keller (2003a) believes the third step in building a strong brand is eliciting consumer responses to the brand by means of brand judgment and brand feelings. Brand judgments refer to the cognitive evaluation of the overall superiority, quality, credibility, and consideration of the brand. This aspect of brand response evaluates the functional and symbolic aspects of the brand in reference to its competition to determine which product is superior. Another aspect of this step is the elicitation of an affective response from the consumer. Brand feelings refer to evocation of feelings and emotions from consumers about themselves and others due to the brand. The judgments and feelings toward the brand on behalf of the consumer impact the relationship and level of identification that the consumer has toward the brand and fellow consumers. The final step, brand resonance, refers to the characteristics of the relationship between the consumer and the brand and the level of time and effort spent on behalf of the consumer towards the consumption of the target brand. Brand resonance can be characterized by the bond the consumer shares with the brand as well as the amount of effort the consumer exerts to consume the brand. Brand resonance has been defined by four dimensions: behavioral loyalty, attitudinal attachment, sense of community, and active engagement.

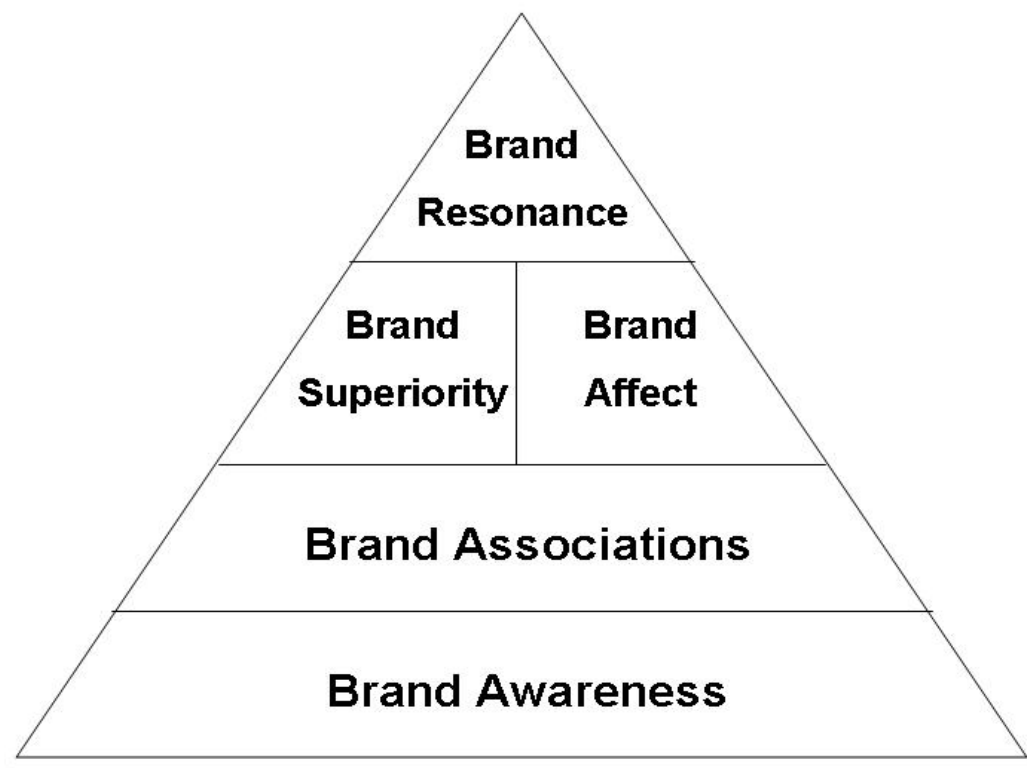

Figure 2. Conceptual framework

Adapted brand equity pyramid. An adapted pyramid can be seen in Figure 2. Although the conceptualization differs, the sequential nature of Keller's conceptualization was adopted in this study. Sequential means that consumers become loyal to a brand by first being aware of the brand, holding specific mental thoughts (or associations) regarding the brand, and having a particular emotional or rational response to the brand in order to decide to consume the brand. The main difference between the conceptual framework for this study and Keller's conceptualization was the elimination of brand performance. Keller posits that the main aspect of brand performance is the perception of quality on behalf of the consumer. Numerous authors (Mullin, et al., 2007; Ross, 2006; Ross, 
Russell, \& Bang, 2008) contend that the quality of the core product of spectator sport services cannot be directly controlled and as a result, brand performance should be viewed simply as a specific brand association. Since the study tested the consumer-based brand equity model in the sport setting, this modification was necessary. Therefore, perceptions of quality were simply viewed as specific thoughts that come to mind when consumers retrieve information regarding their favorite brand. An evaluation of brand performance and other thoughts related to the brand was captured by means of the brand superiority measure.

An evaluation of the functional aspects of the brand (consumer judgments) was represented by the brand superiority measure. Brand superiority represents the consumers' cognitive evaluation of the overall advantage that a particular brand holds over its competitors. Unlike the consumer judgments measure posited by Keller, there is an important distinction between consumer judgments and brand superiority. Consumer judgment, most often measured as brand attitudes, is a transaction-specific, broad measure that fails to capture the true purpose of brand management strategy. The brand superiority measure captured the uniqueness and differentiation that consumers perceive when they evaluate a brand in relation to its competitors. In this sense, this measure was attempting to capture one of the ultimate goals of effective branding: the creation of a brand that is unique or distinct from its competitors.

\subsection{Theoretical Framework}

The study was based upon two theoretical foundations. First, the conceptualization of brand equity followed Bagozzi's (1992) cognitive appraisal - emotional response - behavioral intentions model. Previous conceptualizations of brand equity have posited that brand associations lead directly to behavioral intentions (i.e. behavioral loyalty). For example, Gladden and Funk (2001) and Bauer, Sauer, and Exler (2008) proposed models of brand equity that examined the link between brand associations and brand loyalty. In Gladden and Funk's model, there was no consideration for an attitudinal or emotional response to the brand associations consumers have toward the brand thus impacting their behavioral intentions. Bauer et al. (2008) acknowledged brand attitudes in their model but did not test the moderating effect it may have had on the attributes and benefits aspect of brand associations in their model. However, brand associations are simply cognitive appraisals of the brand; their needs to be an emotional response element that accounts for the link between brand associations and behavioral intentions. Therefore, this conceptual framework posits that brand affect and brand attitude moderate the relationship between brand associations and brand resonance (behavioral intentions measure). This model has not been conceptualized and empirically tested in previous literature yet its foundation is based on the sound theoretical framework of Bagozzi's attitude model.

The sequence of this model is easy to identify and apply to consumers and their favorite brand. As consumers begin to learn about a potential brand, they are exposed to content regarding the brand from the organization itself directly through marketing communications and indirectly by means of publicity, word of mouth, and media telecasts. These communication channels expose the consumer to the brand and build awareness for the brand in the mind of the consumer. This starts to form the identity of the brand for the consumer. As the brand associations gain depth and breadth, the consumer begins to attach meaning to the associations. For example, the Chicago White Sox ran a marketing campaign that positioned their brand as the "blue-collar, working class team" on the south side of Chicago in comparison to their elitist competition on the north side of town. This campaign was successful and established a positive brand identity based on the brand associations that consumers held for the White Sox. As a result, part of the overall meaning of the brand was formed based on this differentiation with their competition. Therefore, as consumers are exposed to the brand and gain more associations, an overall picture tends to form in their mind.

Next, the consumer responds favorably or unfavorably to the associations they hold for the brand. This response includes an appraisal of the functionality of the brand as well as an evaluation of how the brand makes them feel or how the brand is portrayed. These responses help form the consumer's overall disposition towards the brand. Finally, based on the meaning and responses to the brand, the consumer decides how to engage the brand in a relationship (see Figure 3 for causal model). For consumers that have a highly favorable cognitive and emotional response to the brand, they are more likely to engage in loyal behavior towards the brand. Generally, the consumer is more willing to invest their time, money, and effort on behalf of the brand. This may include joining virtual and actual consumption communities to celebrate the brand, as well as actively engaging in conversation, web searching, and media consumption of the brand consistently over time. These behaviors represent the action loyalty described by Oliver (1999) in his work on the dimensionality of loyalty. 


\subsection{Research Hypotheses}

As seen in Figure 3, the hypothesized model of consumer-based brand equity contains a number of research hypotheses. The following section will detail how those research hypotheses were developed and how they will be tested.

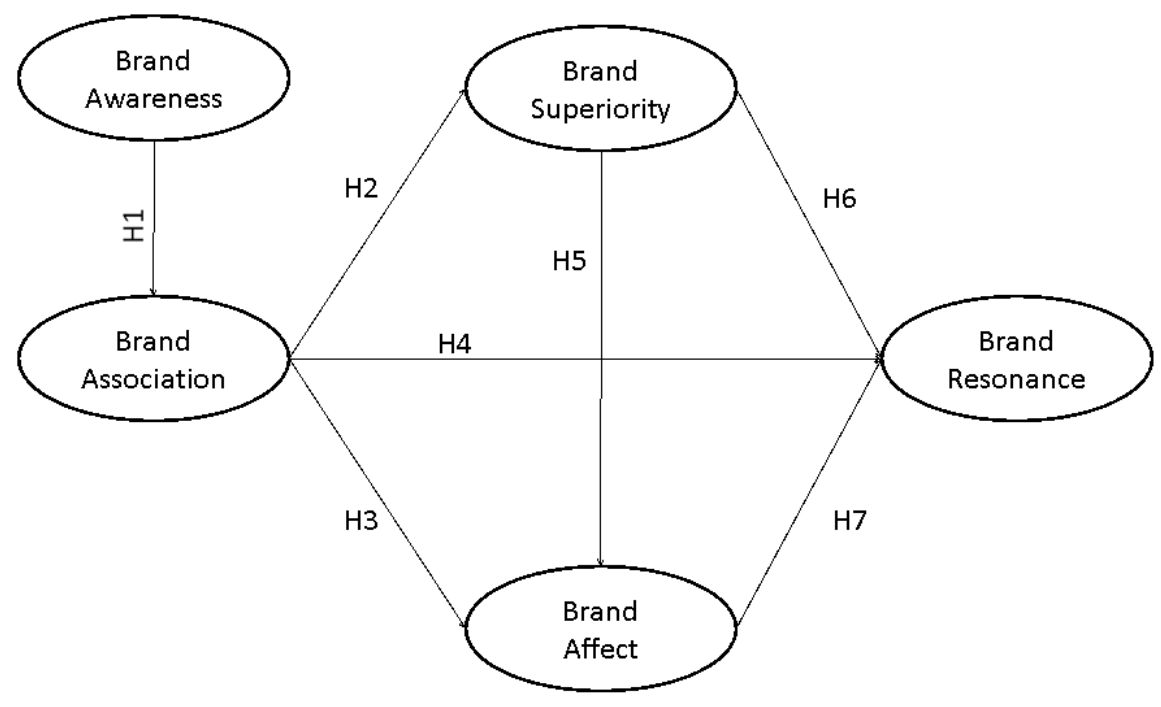

Figure 3. Hypothesized Causal Model

Brand awareness and brand associations. Brand awareness has been characterized as the launching point for building brand equity (Keller, 1993). In order for individuals to hold favorable thoughts regarding a brand, they must first be aware of the brand. Therefore, numerous authors have hypothesized that brand awareness influences brand associations (Aaker, 1996; Gladden, et al., 2001; Keller, 1993; Ross, 2006; Ross et al, 2008). Consumers who have a high level of familiarity with a brand have more depth and breadth of thoughts about the brand and are more likely to have a positive disposition toward the brand (Campbell \& Keller, 2003). Therefore:

$\mathrm{H}_{1}$ : Consumers' level of brand awareness will have a positive effect on the strength of brand associations they hold.

The role of brand associations. Numerous authors have characterized brand awareness and brand associations as the primary components of brand equity (Berry, 2000; Keller, 1993; Ross, 2006). The insinuation of this characterization is that in order to build positive brand equity, a consumer must be aware and hold positive, favorable, and unique associations for a given brand (Bauer et al., 2008; Keller, 1993). However, there is considerable empirical evidence that suggests it requires more than mere awareness and associations to influence consumer decision-making. For example, Faircloth, Capella, and Alford (2001) showed that a consumer's cognitive evaluation of brand associations influenced the brand equity of a given product. The implications of these results suggest that mere mental thoughts that come to mind (i.e. brand associations) and awareness are not enough to drive consumers' behavioral intentions. This suggests that consumers evaluate the thoughts they hold for the brand and it is this evaluation that ultimately drives their behavior toward the brand. In the context of this study, consumers will evaluate the brand associations they hold in an effort to determine the overall superiority of the brand in relation to its competitors.

Brand associations have been shown to be a critical role in a consumer's brand selection (Aaker, 1991; Bauer et al., 2008; Gladden \& Funk, 2001; Keller, 1993, 2003; Ross et al., 2006). Consumers learn about brands through 
marketing messages and direct experience with the product. As a result, these experiences aid in the formation of positive and negative thoughts regarding the brand. Numerous authors have posited that consumers react to the brand associations they hold for a product and as a result, this reaction has a drastic impact on their decision-making (Bauer et al., 2005; 2008; Gladden \& Funk, 2001; Keller, 1993; Pappu, Quester, \& Cooksey, 2005). As mentioned above, consumers' cognitive evaluations are based upon the brand associations they hold. Besides cognitive evaluations, it can be suggested that consumers will have an affective response to the brand associations they hold for a given brand. For example, organizations make emotional appeals to consumers through advertisements in order to plant specific associations in the mind of consumers in an attempt to elicit a positive emotional response and guide intentions toward the product. Similar to the earlier argument, mere awareness and associations are not enough to drive consumers' behavioral intentions. Instead, consumers will develop affective responses to the associations they hold for a specific product and this response is a critical link between brand associations and behavioral intentions. Therefore:

$\mathrm{H}_{2:}$ The strength of brand associations will have a positive effect on consumers' perception of brand superiority.

$\mathrm{H}_{3}$ : The strength of brand associations will have a positive effect on consumers' level of brand affect.

$\mathrm{H}_{4}$ : The strength of brand associations will not have a direct effect on consumers' level of brand resonance.

Brand superiority and brand affect. Consumers are consistently evaluating and affectively responding to communications and direct experience with a given product. Previous research has attempted to ascertain the temporal order of these cognitive evaluations and affective responses. For example, scholars of the quality and satisfaction literature have maintained that quality assessments (cognitive) influence the level of consumer satisfaction (affective) (Anderson \& Fornell, 1994; Athanassopoulous, 2000; Bolton \& Lemon, 1999; Cronin, Brady, \& Hult, 2000; Gotlieb, Grewal, \& Brown, 1994). The theoretical explanation can be found in Bagozzi's (1992) attitude formation framework. He concludes that individuals make cognitive appraisals, followed by an affective response, which impacts their future intentions. Therefore, this study will examine the relationship between brand superiority (cognitive evaluation) and brand affect (affective response). Previous research suggests that consumers will have an affective response based on their cognitive evaluation of the superiority of the brand. Therefore:

$\mathrm{H}_{5}$ : Consumers' perception of brand superiority will have a positive effect on their level of brand affect.

Brand superiority, brand affect, and brand resonance. Consumers make a myriad of judgments that can influence the likelihood of consuming a particular good or service. Among these judgments, cognitive evaluations such as quality assessments have been extensively examined by previous research (Brady \& Cronin, 2001; Cronin, Brady, \& Hult, 2000; Dabholkar, Shephard, \& Thorpe, 2000; Gotlieb, Grewal, \& Brown, 1994; Parasuraman, Zeithaml, \& Berry, 1994). Furthermore, research into brand attitudes has shown that a consumer's attitude toward a brand and/or advertisement is a significant predictor of his or her behavioral intentions toward a given brand (Suh \& Yi, 2006) Also, it has been shown that brand attitudes significantly influence the level of brand equity for a product (Faircloth et al., 2001). The overarching conclusion of this research is that cognitive evaluations have an influence on consumer's behavioral intentions. In the confines of this study, the overall cognitive evaluation of a brand's superiority in comparison with its competitors will be examined. Based on aforementioned evidence, it can be suggested that a consumer's evaluation of a brand's superiority may influence the likelihood that they will purchase the product and engage in repeat buying behavior. Therefore:

$\mathrm{H}_{6}$ : Consumers' perception of brand superiority will have a positive effect on their level of brand resonance.

Companies have been known to craft advertising messages and construct product packaging that attempts to tap into a consumer's feelings toward a certain issue or product. Additionally, previous research has examined how a consumer's affective response influences their purchasing decisions and a tentative conclusion is that emotions have been found to play a vital role in consumer decision making (Chaudhuri \& Holbrook, 2001; Mano \& Oliver, 1993; Matzler, Bidmon, \& Grabner-Krauter, 2006; Mooradian \& Oliver, 1997; Richins, 1997; Thompson, Rindfliesch, \& Arsel, 2006). For example, brand affect has been found to be a significant predictor of consumer loyalty (Chaudhuri \& Holbrook, 2001). This suggests that a consumer's a affective response plays a significant role in forming their behavioral intentions toward a given product or brand. Therefore, in regards to this study, a consumer's level of affect toward a particular brand may influence their loyalty and engagement for the brand. Therefore:

$\mathrm{H}_{7}$ : Consumers' level of brand affect will have a positive effect on their level of brand resonance. 


\section{Method}

\subsection{Research Setting and Sample}

The survey questionnaire contained several sections of service brand-related measures. Additionally, respondents were provided with a focal services brand (New York Yankees), which allowed for a more accurate comparison across contexts. The New York Yankees brand was selected due to the high level of awareness the sport service brand enjoys in its' respective product category. A convenience sample of 840 non-student residents of a mid-sized southeastern community completed the aforementioned survey questionnaire. Trained surveyors collected the data from local community members. Of the 840 questionnaires, 787 were deemed usable for analysis, which constitutes a $93.6 \%$ response rate. Of this number, $496(63 \%)$ respondents were female while $291(37 \%)$ respondents were male. The average age of the respondents was 35.4 years of age. There were $547(69.5 \%)$ Caucasian, $136(17.2 \%)$ African-American, 49 (6.2\%) Latino, 25 (3.1\%) Asian, and nine (1.1\%) Native American respondents. There were 21 respondents that chose not to disclose their race.

\subsection{Measures}

\subsubsection{Brand Awareness}

This study adapted the five-item scale utilized by Yoo et al. (2000) in their examination of the relationship between the marketing mix elements and brand equity. They constructed a brand awareness measure that included items that represented brand recall and brand recognition. All of the items were measured on a 7-point Likert scale ranging from strongly disagree (1) to strongly agree (7).

\subsubsection{Brand Association}

Brand associations are defined as thoughts regarding a brand in the mind of the consumer (Aaker, 1991). Brand associations were characterized as attributes or benefits in this study whereas the attitudinal component in this study was captured by brand superiority. Brand associations were measured by the scale created by Gordon, James, and Yoshida (2016) whereas service brand associations were measured along five dimensions (benefits, attributes, service, discount, social benefits) with a total of 18 items.

\subsubsection{Brand Superiority}

According to Keller (2003a), brand superiority is considered one aspect of a consumer's overall, cognitive evaluation of a focal brand. The measure of brand superiority included three items based on suggestions by Keller (2003a). Brand superiority is meant to capture the differentiation, uniqueness, and superiority of the target brand thus an item that captures this difference is necessary. Additionally, two items were added that measure value and quality perceptions on behalf of the consumer. All of the items were measured on a 7-point Likert scale ranging from strongly disagree (1) to strongly agree (7).

\subsubsection{Brand Affect}

The brand affect measure was adapted from Fuller, Matzler, and Hoppe's (2008) brand passion measure and contained six items that were adapted for the specific context of this study. These items accounted for the emotional impact of the brand on the consumer and this will provide sport organizations a barometer in terms of how effective their efforts have been in providing a pleasurable experience for consumers. All of the items were measured on a 7-point Likert scale ranging from strongly disagree (1) to strongly agree (7).

\subsubsection{Brand Resonance}

Brand resonance can be characterized by the extent to which consumers have a relationship with the brand as well as the subsequent behavior they engage in on behalf of the brand (Keller, 2003a). In the context of this study, brand resonance is comprised of three dimensions: behavioral loyalty, sense of community, and active engagement. The brand resonance measure included 13 items adapted from Keller's (2003a) item suggestions. The behavioral loyalty aspect of the measure included four items that capture the behavioral intentions of consumers toward a target brand. The sense of community measure was represented by four items that measures the level of connection and depth of relationship that the consumer shares with other consumers of the brand. Active engagement represents the ultimate level of brand engagement and was represented by five items which were measured on a seven point Likert-type scale from strongly disagree (1) to strongly agree (7).

\subsection{Data Analysis}

In order to evaluate the relationships proposed in this study, this study incorporated the recommendations from Kline (2005) in regards to how to evaluate a model that has measurement and structural components. Evaluation of the 
model involves two steps where the basic principles of analyzing a CFA and structural model apply. The first step of this approach was to examine the measurement model by means of a confirmatory factor analysis in order to further the validation process. To achieve this, the overall sample $(\mathrm{N}=787)$ was randomly split into two separate samples $(\mathrm{N}=393$ and $\mathrm{N}=394)$. The first sample was used to refine and validate the measurement model. The second sample was utilized to evaluate the structural model to assess the relationships between the proposed constructs as well as test the hypothesized relationships in the study.

\section{Results}

\subsection{Assessment of Measures}

In regards to psychometric testing, all factors had composite reliability scores that were higher than the suggested cutoff point of .70, which provides evidence that the constructs are internally consistent (Bagozzi \& Yi, 1988). All of the measurement items loaded on their respective factors, with loading values ranging from .391 to .967 with the exception of one item (see Table 1 for psychometrics). There were two brand awareness items that had low factor loadings, which were removed from further analysis. Another brand awareness item exhibited a low factor loading (.391) but was retained due to its overall conceptual importance to the construct. In regards to the brand association measure, the dimensions of discount and social benefits were dropped after initial analysis due to low factor loading of their respective items and an unacceptable initial overall model fit. The final brand association measure was comprised of three dimensions (attributes, benefits, service) with 12 total items. Further, an attribute item under brand association exhibited a low factor loading (.489) but was retained due to its conceptual importance. Finally, it was found that brand resonance consisted of two dimensions (active engagement and sense of community) instead of the proposed three dimensions. The behavioral loyalty items cross-loaded with active engagement indicating a lack of distinction between the two dimensions in this context. After an examination of the final items in this dimension, it was determined that active engagement was the appropriate label for the dimension.

Convergent validity was assessed by computing the AVE scores for the proposed constructs (Fornell \& Larcker, 1981). The AVE scores ranged from .64 to .85 , which illustrated the presence of convergent validity among all the constructs (greater than .50). Discriminant validity was assessed by comparing the average variance extracted of each construct with the squared multiple correlation with any other construct (Fornell \& Larcker, 1981). One potential issue was between brand awareness and brand affect. The squared correlation between the two constructs was .67 while the AVE score for brand awareness is .64.

Table 1 . Service brand equity scale psychometric properties

\begin{tabular}{lcccc}
\hline \multicolumn{1}{c}{ Construct } & Item & $\begin{array}{c}\text { Factor } \\
\text { loading }\end{array}$ & $\begin{array}{c}\text { Composite } \\
\text { reliability }\end{array}$ & AVE \\
\hline Brand awareness & & & .757 & .64 \\
& Aw3 & .391 & & \\
Aw4 & .824 & & \\
Brand affect & Aw5 & .949 & & .85 \\
& & & .940 & \\
& Aff2 & .806 & & \\
& Aff3 & .830 & & \\
& Aff4 & .822 & & \\
& Aff5 & .752 & & \\
& Aff6 & .839 & &
\end{tabular}

Brand superiority

.904

$\begin{array}{ll}\text { Sup2 } & .807 \\ \text { Sup3 } & .831 \\ \text { Sup4 } & .823\end{array}$




$\begin{array}{ll}\text { Sup5 } & .752 \\ \text { Sup6 } & .840\end{array}$

Brand resonance

Active engagement

$\begin{array}{ll}\text { AE1 } & .830 \\ \text { AE2 } & .833 \\ \text { AE3 } & .872 \\ \text { AE4 } & .929 \\ \text { AE5 } & .916 \\ \text { AE6 } & .818 \\ \text { AE7 } & .894 \\ \text { AE8 } & .926 \\ \text { AE9 } & .878\end{array}$

Sense of community

$\begin{array}{ll}\text { Com1 } & .879 \\ \text { Com2 } & .883 \\ \text { Com3 } & .883 \\ \text { Com4 } & .722\end{array}$

Brand association

Attribute

Att2

Att3

Att4

Benefit

$\begin{array}{ll}\text { Ben1 } & .829 \\ \text { Ben2 } & .819 \\ \text { Ben3 } & .749 \\ \text { Ben4 } & .815 \\ \text { Ben5 } & .790\end{array}$

Service

$\begin{array}{ll}\text { Ser1 } & .684 \\ \text { Ser2 } & .920 \\ \text { Ser3 } & .967\end{array}$

Although there appears to be an issue with discriminant validity, an examination of the items and operational definitions clearly indicates that they are conceptually distinct. Brand awareness measures the mere presence of the brand in the mind of the consumer while brand affect measures the consumers' emotional response to the brand. 
Another issue with discriminant validity was between brand affect and brand resonance. The squared correlation between brand affect and brand resonance is .92 whereas the AVE scores are .85 and .84 respectively.

In an effort to uncover further evidence of construct validity, the degree to which the proposed measurement model fit the data was evaluated by global fit indices. The chi-square value was significant due to the large sample size. The ratio of the square value to the degrees of freedom was $4.7\left(\mathrm{x}_{2}=3001 ; \mathrm{df}=634\right)$ The CFI and TLI values were 0.928 and 0.920 respectively. Both of these values were at or above the .90 threshold for an acceptable model fit. The RMSEA value of 0.07 was within the range of an acceptable fit of the data to the model. Finally, the SRMR value of 0.051 was well below the recommended cutoff value of .08. Overall, there is sufficient global fit evidence to suggest that the services brand equity measurement model is an adequate fit to the data.

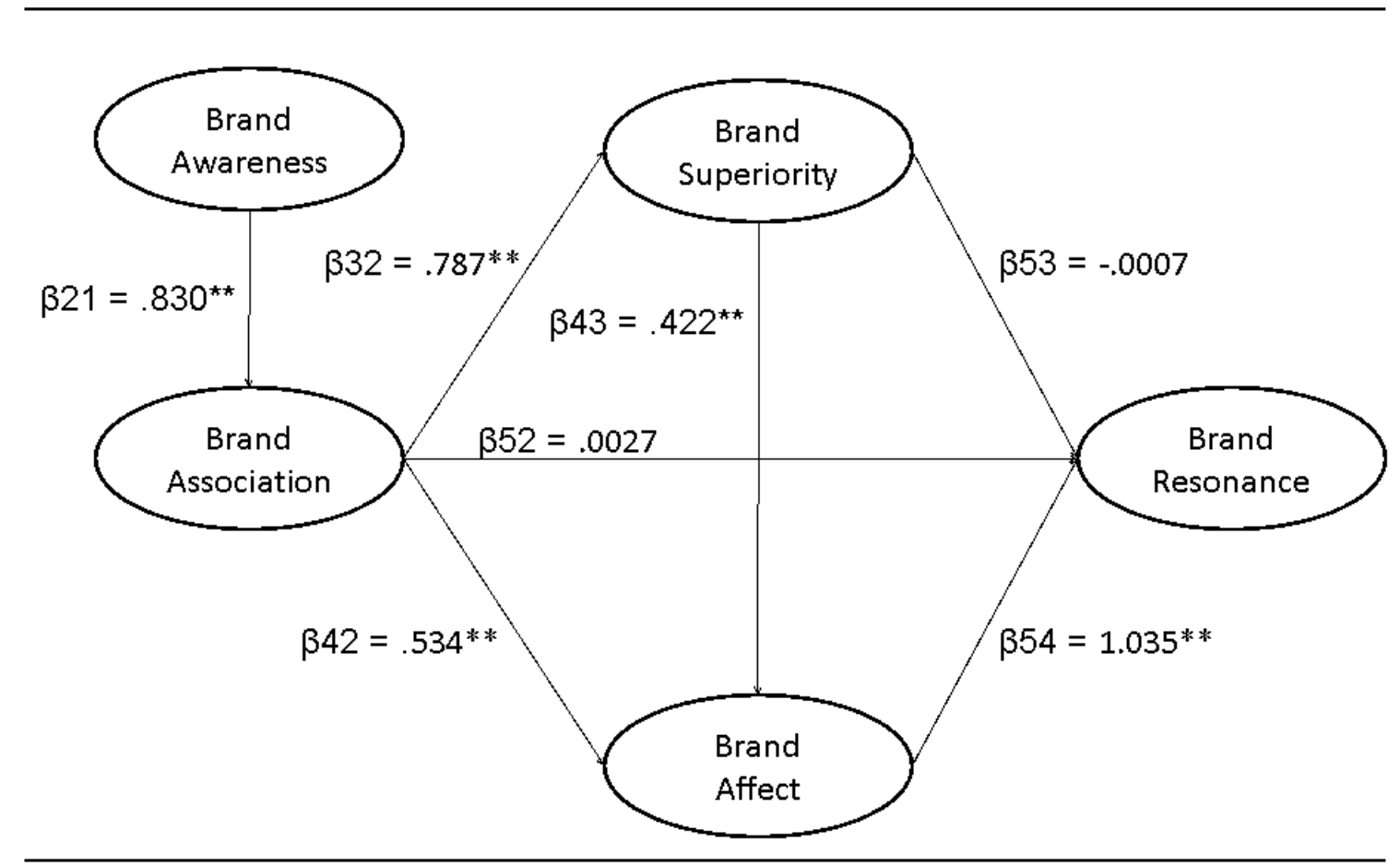

Note. $\mathrm{N}=394 ; \mathrm{x}^{2} / \mathrm{df}=4.92 ; \mathrm{CFI}=.925 ; \mathrm{TLI}=.918 ; \mathrm{RMSEA}=0.071 ;{ }^{*} \mathrm{p}<.05 ;{ }^{\star *} \mathrm{p}<.01$

Figure 4. Service brand equity structural model

\subsection{Hypothesis Testing}

Figure 4 illustrates the hypothesized relationships among the proposed constructs. The global fit indices indicate that the hypothesized structural model exhibits a good fit to the data. The chi-square statistic was significant due to the large sample size and the chi-square to degrees of freedom ratio was $4.9\left(\mathrm{x}_{2}=3130 ; \mathrm{df}=635\right)$. The CFI and TLI values were .925 and .918 respectively. The RMSEA value for the services model was 0.71 while the SRMR was 0.055. Collectively, these results indicate that the hypothesized model represents a good statistical fit to the data.

The hypothesized relationships among the proposed constructs were examined as well. The path between brand awareness and brand association was statistically significant $\left(\beta_{21}=.830 ; \mathrm{p}<.01\right)$, indicating that awareness had a positive impact on brand association as expected. This finding supports $\mathrm{H}_{1}$. Brand associations were found to have a positive effect on both brand superiority $\left(\beta_{32}=.787 ; \mathrm{p}<.01\right)$ and brand affect $\left(\beta_{42}=.534 ; \mathrm{p}<.01\right)$. These findings supported $\mathrm{H}_{2}$ and $\mathrm{H}_{3}$ respectively. Brand association did not have a positive effect on brand resonance $\left(\beta_{52}=0.0027\right.$; n.s.), which supports $\mathrm{H}_{4}$. The path coefficient between brand superiority and brand affect was significant $\left(\beta_{43}=.422\right.$; $\mathrm{p}<.01)$ which indicated that brand superiority had a positive effect on brand affect yet brand superiority did not have 
a significant effect $\left(\beta_{53}=-.0007\right.$; n.s.) on brand resonance. These findings supported $\mathrm{H}_{5}$ but did not support $\mathrm{H6}$. Finally, brand affect was found to have a positive effect on brand resonance $\left(\beta_{54}=1.035 ; \mathrm{p}<.01\right)$, which supported $\mathrm{H}_{7}$.

\section{Conclusion and Implications}

The majority of the research hypotheses in this study were confirmed. In one case, the results merely confirmed what brand scholars have posited previously (e.g., the relationship between brand awareness and brand associations). However, the results also added considerably to the body of literature by refuting previous findings regarding the role of brand associations in influencing consumer loyalty. The results of this study indicated that the process toward building brand equity involves more than just constructing mere associations. Associations influence the cognitive evaluations and affective responses to the brand on behalf of consumers, which directly influence (in this study, only brand affect) consumers' behavioral intentions toward the brand (brand resonance).

The current study makes a contribution to the literature and marketing practice in several ways. First, the construction of a general framework that relates well-established drivers of brand equity (brand awareness and brand associations) to consumer behavioral outcomes was validated. Additionally, from a theoretical standpoint, the model in this study challenged the widely accepted notion that brand associations lead directly to behavioral outcomes. No previous studies have assessed the relationship among brand associations, consumers' cognitive and affective responses, and consumers' behavioral outcomes. The result of operationalizing Keller's (2003a) consumer-based brand equity pyramid was to provide guidance to practitioners for brand building. As Keller states "one CBBE application is in terms of brand tracking and providing quantitative measures of the success of brand-building efforts" (p.96). This model provides the initial reliability and validity evidence for a method for understanding how consumers understand, feel, and initiate effort in regards to a service brand.

A second contribution of this study was the utilization of a more accurate and consumer-based measure of service brand associations. Previous measures of brand associations have shared some common characteristics. First, other measures have combined constructs that are conceptually distinct (Yoo et al., 2000; brand awareness and brand associations) or have not elicited brand associations directly from consumers (Bauer et al., 2008; Gladden \& Funk, 2002). The brand association measure in this study accounted for both of the aforementioned limitations. Brand associations were elicited directly from consumers in the service context and the role of brand awareness and brand associations in building brand equity was assessed separately. The result is a foundational measure that can be utilized in multiple service contexts.

As a third contribution to the literature, this study lays the foundation for our understanding of how consumers perceive service brands. Brand associations were found to have a greater impact on consumers' affective response to the brand while the same magnitude of relationship was not assessed for cognitive evaluations (brand superiority). The practical implications of this finding is clear in that services marketers need to focus on the benefits of their brand and how those benefits will impact consumers' emotions. More importantly, the lack of a direct effect of brand superiority on brand resonance was an unexpected result. A direct relationship between brand superiority and brand resonance was expected, as illustrated by the aforementioned research hypothesis as well as the theoretical framework. Instead, it was found that brand superiority did not directly influence brand resonance but it did significantly impact brand affect while brand affect had a significant relationship with brand resonance in this study. This finding suggests that cognitive evaluations and affective responses work simultaneously to influence the degree to which a brand "resonates" with consumers. Consumers not only "think" about the associations they hold for a brand but they also evaluate their "feelings" about the brand before taking action on behalf of the brand. This finding illustrates the importance of emotions in the consumer decision-making process.

The results of this study provide empirical evidence of the importance that brand associations play in the overall brand-building process. However, unlike previous research, this study has shown that brand associations directly influence consumers' cognitive evaluations and affective responses to the brand, not their behavioral intentions. Therefore, the model presented in this study provides a "brand barometer" for understanding how much progress a company has made in their attempts to manage and build its brand. Furthermore, this study has operationalized a new set of consumer behavioral outcomes. This study provides evidence that consumers actively connect to brands on a regular basis as well as put forth effort to connect with other consumers on behalf of the brand.

This finding has implications for brand managers and scholars alike. It illustrates the powerful effect that strong brands can have on consumers in that the strongest brands will empower consumers to act as brand "evangelists" or "missionaries" (Keller, 2003b). The importance of consumers to help build this "sense of community" around the focal brand and foster identification among consumers has been found in multiple settings (Yoshida, Gordon, James, 
\& Heere, 2015; Yoshida, Heere, \& Gordon, 2015). Consumers of strong brands will be compelled to continually learn about the brand and share their beliefs about the brand with other consumers. Brand resonance also provides marketers with a tangible goal to achieve in regards to their brand-building activities. Marketers can assess the degree to which consumers are "actively engaged" with their brand as well as how much effort consumers are putting forth to connect with other current and potential consumers of the brand.

From a practical standpoint, the results highlight the importance of imparting brand associations into the mind of the consumer through marketing messages. It is important to highlight the experiential, visceral benefits of product consumption. Marketers should focus their communication content on how it feels to consume the product and how these feelings are different from competitor brands. The model suggests that these types of thoughts will impact how consumers feel about the brand, a critical link to impacting their behavioral intentions.

\section{References}

Aaker, D.A. (1991). Managing brand equity: Capitalizing on the value of a brand name. New York: Free Press.

Aaker, D.A. (1996). Building strong brands. New York: McMilian.

Akin, M. (2016). Measuring spectator-based brand equity in the Turkish professional soccer clubs. International Review of Management and Business Research, 5(4), 1324-1341.

Anderson, E., \& Fornell, C. (1994). A customer satisfaction research prospectus. In R. T. Rust \& R. L. Oliver (Eds.), Service Quality: New Directions in Theory and Practice (pp. 41-268). Thousand Oaks, CA: Sage Publications. https://doi.org/10.4135/9781452229102.n11

Bagozzi, R.P. (1992). The self-regulation of attitudes, intentions, and behaviors. Social Psychology Quarterly, 55, 178-184. https://doi.org/10.2307/2786945

Bagozzi, R.P., \& Yi, Y. (1988). On the evaluation of structural equation models. Journal of the Academy of Marketing Science, 16(1), 74-94. https://doi.org/10.1007/BF02723327

Baldinger, A., \& Robinson, J. (1996). Brand loyalty: The link between attitude and behavior. Journal of Advertising Research, 36(6), 22-34.

Bauer, H.H., Sauer, N.E., \& Exler, S. (2008). Brand image and fan loyalty in professional team sport. Journal of Sport Management, 22(2), 1-25. https://doi.org/10.1123/jsm.22.2.205

Bauer, H.H, Sauer, N.E., \& Schmitt, P. (2005). Customer-based brand equity in the team sport industry. European Journal of Marketing, 39(5/6), 496-513. https://doi.org/10.1108/03090560510590683

Bello, D.C., \& Holbrook, M.B. (1995). Does the absence of brand equity generalize across product classes?. Journal of Business Research, 34(2), 125-131. https://doi.org/10.1016/0148-2963(95)00008-G

Berry, L. (2000). Cultivating service brand equity. Journal of the Academy of Marketing Science, 28, 128-137. https://doi.org/10.1177/0092070300281012

Bolton, R.N., \& Lemon, K.N. (1999). A dynamic model of customer's usage of services: Usage as an antecedent and consequence of satisfaction. Journal of Marketing Research, 36, 171-186. https://doi.org/10.2307/3152091

Boone, L.E., Kochunny, C.M., \& Wilkins, D. (1995). Applying the brand equity concept to Major League Baseball. Sport Marketing Quarterly, 4(3), 33-42.

Brady, M.K., \& Cronin, J.J. (2001). Some new thoughts on conceptualizing perceived service quality: A hierarchical approach. Journal of Marketing, 65, 34-49. https://doi.org/10.1509/jmkg.65.3.34.18334

Brady, M.K., Cronin, J.J., Fox, G.L., \& Roehm, M.L. (2008). Strategies to offset performance: The role of brand equity. Journal of Retailing, 2, 151-164. https://doi.org/10.1016/j.jretai.2008.04.002

Campbell, M.C., \& Keller, K.L. (2003). Brand familiarity and advertising repetition effects. Journal of Consumer Research, 30, 17-35. https://doi.org/10.1086/376800

Chaudhuri, A., \& Holbrook, M.B. (2001). The chain of effects from brand trust and brand affect to brand performance: The role of brand loyalty. Journal of Marketing, 65(2), 81-93. https://doi.org/10.1509/jmkg.65.2.81.18255

Cobb-Walgren, C.J., Ruble, C.A., \& Donthu, N. (1995). Brand equity, brand preference, and purchase intent. Journal of Advertising, 24(3), 25-37. https://doi.org/10.1080/00913367.1995.10673481 
Cronin, J.J., Brady, M.K., \& Hult, G.T. (2000). Assessing the effects of quality, value, and customer satisfaction on consumer behavioral intentions in the service environment. Journal of Retailing, 76(2), 193-218. https://doi.org/10.1016/S0022-4359(00)00028-2

Dabholkar, P.A., Shepherd, C.D., \& Thorpe, D.I. (2000). A comprehensive framework for service quality: An investigation of critical conceptual and measurement issues through a longitudinal study. Journal of Retailing, 76(2), 139-173. https://doi.org/10.1016/S0022-4359(00)00029-4

Davcik, N.S., \& Sharma, P. (2015). Impact of product differentiation, marketing investments, and brand equity on pricing strategies: A brand level investigation. European Journal of Marketing, 49(5/6), 760-781. https://doi.org/10.1108/EJM-03-2014-0150

Faircloth, J.B, Capella, L.M., \& Alford, B.L. (2001). The effect of brand attitude and brand image on brand equity. Journal of Marketing Theory and Practice, 9(3), 61-75. https://doi.org/10.1080/10696679.2001.11501897

Fuller, J., Matzler, K., \& Hoppe, M. (2008). Brand community as a source of innovation. Journal of Product Innovation Management, 25(6), 608-619. https://doi.org/10.1111/j.1540-5885.2008.00325.x

Gladden, J., \& Funk, D. (2002). Developing an understanding of brand associations in team sport: Empirical evidence from consumers of professional sport. Journal of Sport Management, 16, 54-81. https://doi.org/10.1123/jsm.16.1.54

Gladden, J., \& Milne, G. (1999). Examining the importance of brand equity in professional sports. Sport Marketing Quarterly, 8, 21-29.

Gladden, J.M., \& Funk, D.C. (2001). Understanding brand loyalty in professional sport: Examining the link between brand associations and brand loyalty. International Journal of Sports Marketing and Sponsorship, 3, 67-95. https://doi.org/10.1108/ijsms-03-01-2001-b006

Gordon, B.S., James, J.D., \& Yoshida, M. (2016). The development of brand association measures in multiple product categories: New findings and implications for goods and service brands. International Journal of Business Administration, 7(3), 140-152. https://doi.org/10.5430/ijba.v7n3p140

Gotlieb, J.B., Grewal, D., \& Brown, S.W. (1994). Consumer satisfaction and perceived quality: Complementary or divergent constructs? Journal of Applied Psychology, 79(6), 132-160. https://doi.org/10.1037/0021-9010.79.6.875

Hair, J.F., Black, W.C., Babin, B.J., Anderson, R.E., \& Tatham, R.L. (2006). Multivariate data analysis (6 ${ }^{\text {th }}$ ed.). Upper Saddle River, NJ: Prentice-Hall.

Kayaman, R., \& Aralsli, H. (2007). Customer-based brand equity: Evidence from the hotel industry. Managing Service Quality, 17(1), 92-109. https://doi.org/10.1108/09604520710720692

Keller, K.L. (1993). Conceptualizing, measuring, and managing customer based brand equity. Journal of Marketing, 57(1), 1-22. https://doi.org/10.2307/1252054

Keller, K.L. (2003a). Strategic brand management: Building, measuring, and managing brand equity ( $2^{\text {nd }}$ ed.). Boston, MA: Pearson Education.

Keller, K.L. (2003b, March). Brand synthesis: The multidimensionality of brand knowledge. Journal of Consumer Research, 29, 595-600. https://doi.org/10.1086/346254

Kline, R.B. (2005). Principles and practice of structural equation modeling. New York: Guilford Press.

Mano, H., \& Oliver, R.L. (1993). Assessing the dimensionality and structure of the consumption experience: evaluation, feeling, and satisfaction. Journal of Consumer Research, 20, 451-66. https://doi.org/10.1086/209361

Marketing Science Institute. (2008-2010). Current Research Priorities. Retrieved February 1, 2009, from http://www.msi.org/about/1999researchpriorities

Matzler, K., Bidmon, S., \& Grabner-Krauter, S. (2006). Individual determinants of brand affect: the role of the personality traits extraversion and openness to experience. Journal of Product and Brand Management, 15(7), 427-434. https://doi.org/10.1108/10610420610712801

Mooradian, T.K., \& Oliver, R.L. (1997). I can't get no satisfaction: The impact of personality and emotion on $\begin{array}{lllll}\text { postpurchase processes. } & \text { Psychology \& }\end{array}$ https://doi.org/10.1002/(SICI)1520-6793(199707)14:4<379::AID-MAR5>3.0.CO;2-6 
Mullin, B.J., Hardy, S., \& Sutton, W. A. (2007). Sport marketing ( $3^{\text {rd }}$ ed.). Champaign, IL: Human Kinetics.

Pappu, R., Quester, P.G., \& Cooksey, R.W. (2005). Consumer-based brand equity: Improving the measurement with empirical evidence. The Journal of Product and Brand Management, 14(2/3), 143-154. https://doi.org/10.1108/10610420510601012

Parasuraman, A., Zeithaml, V., \& Berry, L. (1994). Reassessment of expectations as a comparison standard in measuring service quality: Implications for future research. Journal of Marketing, 58, 6-17. https://doi.org/10.2307/1252255

Park, C.W., MacInnis, D.J., Priester, J., Eisingerich, A.B., \& Iacobucci, D. (2010). Brand attachment and brand attitude strength: Conceptual and empirical differentiation of two critical brand equity drivers. Journal of Marketing, 74, 1-17. https://doi.org/10.1509/jmkg.74.6.1

Richins, M.L. (1997). Measuring emotions in the consumption experience. Journal of Consumer Research, 24, 127-146. https://doi.org/10.1086/209499

Ross, S.D. (2006). A conceptual framework for understanding spectator-based brand equity. Journal of Sport Management, 20, 22-38. https://doi.org/10.1123/jsm.20.1.22

Ross, S.D., James, J.D., \& Vargas, P. (2006). Development of a scale to measure team brand associations in professional sport. Journal of Sport Management, 20, 260-279. https://doi.org/10.1123/jsm.20.2.260

Ross, S.D., Russell, S., \& Bang, H. (2008). An empirical assessment of spectator-based brand equity. Journal of Sport Management, 22, 322-337. https://doi.org/10.1123/jsm.22.3.322

Sangster, A., Wolton, J., \& McKenney, S. (2001). The international hotel industry - corporate strategies and global opportunities. London: Travel and Tourism Intelligence.

Simon, C.J., \& Sullivan, M.W. (1993). The measurement and determination of brand equity: a financial approach. Marketing Science, 12(1), 28-52. https://doi.org/10.1287/mksc.12.1.28

Su, J., \& Tong, X. (2015). Brand personality and brand equity: Evidence from the sportswear industry. Journal of Product and Brand Management, 24(2), 124-133. https://doi.org/10.1108/JPBM-01-2014-0482

Suh, J.C., \& Yi, Y. (2006). When brand attitudes affect the customer satisfaction-loyalty relation: The moderating role of product involvement. Journal of Consumer Psychology, 16(2), 145-155. https://doi.org/10.1207/s15327663jcp1602_5

Taylor, S.A., Celuch, K., \& Goodwin, S. (2004). The importance of brand equity to customer loyalty. Journal of Product and Brand Management, 13(4), 217-227. https://doi.org/10.1108/10610420410546934

Thompson, C.J., Rindfleisch, A., \& Arsel, Z. (2006). Emotional branding and the strategic value of the doppelganger brand image. Journal of Marketing, 70(1), 50-64. https://doi.org/10.1509/jmkg.2006.70.1.50

Watkins, B. (2014). Revisiting the social identity-brand equity model: An application to professional sports. Journal of Sport Management, 28, 471-480. https://doi.org/10.1123/jsm.2013-0253

Yoo, B., Donthu, N., \& Lee, S. (2000). An examination of selected marketing mix elements and brand equity. Journal of the Academy of Marketing Science, 28(2), 195-211. https://doi.org/10.1177/0092070300282002

Yoshida, M., Gordon, B.S., James, J.D., \& Heere, B. (2015). Fan community identification: An empirical examination of its outcomes in Japanese professional sport. Sport Marketing Quarterly, 24(2), 105-119.

Yoshida, M., Heere, B., \& Gordon, B.S. (2015). Predicting loyalty through community: Why other fans are more important than our own intentions, our satisfaction, and the team itself. Journal of Sport Management, 29(3), 318-333. https://doi.org/10.1123/jsm.2013-0306 